\title{
TAX LAW AND ITS IMPACT ON THE STATE BUDGET ${ }^{1}$
}

\author{
MÁRIA BUJŇÁKOVÁ2
}

\begin{abstract}
The Author presents some reflections regarding the current role of States and international entities and the role and functioning of law as such in the sphere of public finances and, especially, the fight against tax frauds. She emphasizes that a positive effect may be brought only by acting at the global level and that artificial or even irrational persisting on the State sovereignty or isolated attitude of the States regardless of the "common good of many" can cause the opposite to the desired effect. The State has already implemented a series of measures that should partially reduce tax evasion, but it should be noted that as legislators are looking for ways to prevent tax evasion, taxpayers also use all available means to avoid paying the taxes or minimizing their amount. Mutual cooperation among the countries not only within the EU but globally, should help to improve the situation in tax collection in the future.
\end{abstract}

\section{Keywords}

Tax; tax evasion; tax frauds; EU

JEL Classification: H26, H69, K42

1 This paper was written as a partial output of the research project APVV-16-0160 "Tax evasions and tax avoidance (motivation factors, formation and elimination)", as well as the output of the project VEGA 1/0846/17 "Implementation of the initiatives of the EU institutions in the field of direct taxes and indirect taxes and their budgetary law implications".

2 Associate Professor of Financial Law at the Department of Financial Law, Tax Law, and Economics at the UPJŠ Faculty of Law in Košice. She is a recognized authority in the field of tax law and financial law. So far, she has published over 100 publishing outputs of various categories in aggregate. She is involved in the field of financial and tax law, particularly in the field of direct taxation. She is a member of the Information and Organization Centre for the Research on the Public Finances and Tax Law in the Countries of Central and Eastern Europe. Contact email: maria.bujnakova@upjs.cz. 


\section{Introduction}

Every social establishment necessarily requires some regulation that will ensure order, system, but it will also maintain this order and system while guaranteeing the balance of society. The most important way of social regulation is normative regulation, i.e. regulation performed by social normative systems, by which we understand open dynamic and targeted regulatory systems comprised of social standards in the form of instructions, prohibitions, and permissions (Knapp, 1995: $39)$.

There exist several normative systems operating in society. Law occupies a special position among them, whose norms are, as a rule, formally published and their fulfillment is enforceable by the State. The basic division of law into public and private can already be seen in the work of Roman lawyers, although the significance of understanding both public and the private law had been different from their current perception.

Uplianus characterized public law as one that expresses the interests of the State and expresses the interests of the individual (Ulpianus, D I I I 2). Such a muchsimplified statement in today's modern world must be seen in a wider context, but also in the context of ongoing globalization, and in our conditions even in the context of Europeanization of law. In the theory of law, there exists a considerable number of published monographs that present the views and arguments for dividing the law into private and public. ${ }^{3}$

The introduction to this paper is unusual for still another reason. We live in the 21st century and believe that everything that is happening around us has its justification and the world keeps convincing on what is right and what is not right. Perhaps it would be worth considering our returning to old values, traditions, and sometimes even recollections. When studying the background sources for this paper, which is aimed at examining the current issues of tax law and tax evasion prevention, I received a publication from a colleague of mine, Prof. Bröstl "Institutionalism A New Theory of Procedure, Law, and Democracy". This is a translation of the book by Prof. Oto Weinberger, published in 1995. While studying, anyone would be looking for something that would interest, what has not yet been published and what has not yet been quoted and I can it is original. I was particularly interested in the introductory words by Prof. Bröstl, which are his personal assessment of this book. It certainly is a very interesting reading, and I, being a person who prevailingly comes into contact with the positive law, it gave a great opportunity to explore this positive law in a different context (Weinberger, 1995).

3 Various works of law theorists may be worth mentioning: Harvánek, 2008; Boguszak, 2004; Kubů, 2007; Knapp, 1995; Prusák, 2001; Brôstl, 2004. 
My inner uncertainty and moral pursuit have led me to try and make an attempt at making rational analyses as available as possible. I believed and still believe that human reason is a tool of effective and moral action. Nevertheless, I have never thought that only the reason alone could or should condition our desire or what it is supposed to be - meaning, I have never been a cognitivist (Weinberger, 1992).

The science that wants to clarify and determine human existence must, in addition to raw facts, also take into account institutional reality. According to Weinberger, the law is an institutional reality (Weinberger, 1992). The ontology of Weinberger's institutionalism, therefore, relies on the fact that an individual (as well as human society) may determine their behavior on the basis of practical information and factual information. Weinberger rejects pure normativism, which calls for the ideal being of norms without any direct relation to observable processes. However, he also rejects legal realism, for which the applicable law is just observable and predictable behavior of the legally consistent State. The applicable law, in his view, is precisely that co-existence of norms with behavior and with the existing institutions. Legal norms appertain the law - they are a valid law - because they exist in the context of dealing with real and observable processes (Bröstl, 2004). The existing law consists not only of standards of behavior and of empowering norms, but also of legal principles, the teleological background of law, and of institutionalized legal doctrine and methodology. Weinberger takes the view that law and morality separate from each other as two different normative systems, which, however, work together in conditioning the human behavior (Bröstl, 2004).

In the current world, it is necessary to pay special attention to these institutes also because of the existence of phenomena which in law we may rightly call negative, and whose origin is certainly in morality. According to Weinberger, it is necessary to notionally separate law from morality: a) principles of law are part of the positive law, b) the validity of law is conditional on the present creation, not the moral criteria, c) we have to have a possibility of evaluating (valid or proposed) law, but the validity of law is not subject to the moral filter of an individual judge, an official, etc., d) legal life needs a harmony of moral roles of the decision-making bodies - especially in the sphere of discretion - and their connection to the law that functions as a stand-alone system of norms. Law and morality are concepts that specifically resonate in tax law, and often these concepts are perceived in the application practice. Of many considerations, it is worthwhile to recall one oftenstated thesis, "What is moral does not have to be in accordance with law", but this also holds true vice versa, "what is in accordance with the law, does not always have to be moral". 


\section{Impact of Tax Policy}

Taxes and tax policy are part of the State's budgetary policy and also a tool of the State's economic policy. We may state that it is actually a set of measures by which the State modifies the tax system. Tax policy has its objectives, economic, political, and social ones, and, above all, the tax system is used as a means of achieving them. In particular, the tax policy should be stimulating, i.e. it should promote economic development and entrepreneurial activity. When applying the tax policy, however, it is necessary to take into account the specific features of the specific State, therefore it is not possible to fully apply the tax policy of another State to our conditions. Each State has its own specifics, a certain degree of development, social composition, geographical location, and many other features and specifics, which must also be respected in tax policy.

Tax law as an institution that began to emerge in this country after the year 1992, when we start talking about tax law as a separate branch of law, aims to monitor and regulating those social relationships that also have the attributes of the economy, but on the other hand, they must be regulated by law. Taxes represent a social phenomenon that includes economic, legal, social, sociological, moral, and psychological aspects (Babčák, 2012: 24). In particular, it is possible to influence the resources of public budgets, but also economic policies of the State and the economic development.

Law is, in essence, inseparably linked and connected with the society in which it arises and operates. In addition to this conditionality of law, the social context of its existence may also be identified by the conditionality of the development of social relations by a valid and effective set of legal norms implemented in it. The result of this is that society and law are interrelated, which must be respected and taken into account in their close scrutiny. The tax legislation that the State has in place should create the conditions for the application that will also anticipate the emerging situations in the tax system. Tax law in Slovakia has been undergoing a turbulent development since 1992 and has been marked in particular by the adoption of norms that reflect the change in economic and social conditions. Tax norms have often been adopted in a non-systemic manner, requiring frequent amendments, not to mention subordinate norms that have frequently been in conflict with the applicable legislation. Legal norms in the field of tax law have become obtrusive, not to mention their frequent amendments even through other legislation. In this process of transforming the economy, it was not easy to look for acceptable boundaries between public and private finances, between seeking optimal tax justice and economic development. 
A very substantial change in the concept of tax policy in Slovakia took place in the year 2004, as the Slovak Republic had to adapt its legislation also in the field of taxation at its accession to the European Union (Romanova, 2014; Červená, 2008). Finding an optimally suitable and effective compromise in tax policy implementation to present the interests of the public and the needs of the State is very complex and possibly even unrealistic. We need to take into account all the factors that can affect tax legislation itself. The key factors that affect tax legislation can include the tax law system and the tax system. These concepts are not identical, because each of them expresses different internal arrangement and classification. We could characterize the tax law system as a complex of taxation, and in terms of the classification of the legal norms that govern it, we may talk about the material tax law and procedural tax law. The tax system is a component of the tax system, and it is thus the system of all taxes in the country. The tax system may also be characterized as a concept for a particular group of taxes that are levied and collected in a particular state.

The Slovak Republic needs to adapt its tax system on the one hand to both the internal conditions both in the State and in relation to the European Union and to the international aspects to be taken into account. From the point of view of tax law, it is necessary to say that we should enforce such legislative measures that would be of benefit to the State, that would be equitable and simple for citizens, and would at the same time create some space for the competitiveness of the economy even with regard to foreign relations. It is well known that some regularities and limitations have been defined when accessing the EU, particularly with regard to indirect taxes. The field of direct taxation remained the responsibility of national States.

In this paper, I would like to point out some facts that have a significant influence on the tax law itself on its position and the role it plays in economic processes, but also its importance for the national economy and stable development of the economy in Slovakia. Taxation in every market economy is a frequently discussed professional issue, but also one of the most frequently asked questions by the public. In order to achieve the prosperity of any country, the rational economic policy of the State and a pragmatic financial policy are necessary. If the State wants to focus its economic policy on a particular tracked area, it can do so through the targeted policies that form part of it. Tax policy, whose focus and objectives depend on the economic policy applied by the State, plays an irreplaceable role (Beňová, 2005). An integral part of the economic policy is the tax policy which is defined by some Authors as the application of tax principles and measures so that taxes serve to promote the social and political needs of the State (Schultz, 2007: 117). According to Schultz, tax policy is related to the use of taxes and their instruments, which serve to influence macroeconomic and microeconomic processes in the economy (Schultzov, 2007: 
117). It is generally based on the application of economic policy. For example, in the case of a restrictive economic policy, there is an increase in the tax burden and, in the case of an expansionary economic policy, the tax burden is reduced. The aim of the tax policy is to apply tax principles and measures so that taxes serve to promote the economic, social, and political goals of the State (Schultzov, 2011: 11-12).

According to Sivák (2007: 185) most of the public revenue is received by the State through taxes, so the total tax revenue is decisive. If this is to be most effective, it is necessary to keep in mind, when applying the tax policy, the subject matter of the relevant tax, the method of calculating the tax base, as well as other essential elements of taxes.

Economists perceive the role of taxes not just passively, that is to say, as a source of monetary revenue for public budgets, but also actively, as an action on taxpayers and the entire economic system, which is largely contributed by the legislative framework of tax law and tax proceedings. I present these considerations for two main reasons. The first reason is that the issue of taxation and tax legislation is largely addressed in economic theoretical sources, and the second reason is that it is precisely in the Europeanization of the tax system where taxes, in general, should have an increased share in the presentation in the law science. Why is this my consideration? For a simple reason: any good economic justification and analysis, unless they are reflected in legal form, cannot produce desirable results. I am aware of the fact that these are such attributes of law that also include economic features and mutually intertwine, but that should be the reason for their correct understanding, perception, application, and decision making.

Taxes have existed practically from the time of the formation of organized forms of society, and their development is related to the development of the State and the consolidation of the monetary economy. The evolution of taxes is a reflection of the changes that our society has undergone, reflecting the changes in the functioning of the State, economy, trade, and reflecting the understanding of the notions of justice and good (Medved, 2011: 185).

Taxes represent a social phenomenon that includes economic, legal, social, sociological, moral, and psychological aspects (Babčák, 2012: 24). It is in particular through taxes where it is possible to influence public budgets. Taking into account the fact that tax law as a separate branch of law in legal theory is not always appropriate, it will be necessary to raise this issue on a day-to-day basis through all available means of law enforcement. At the same time, the law is a phenomenon that is inherently inseparable from the society in which it arises and operates. In addition to this conditionality of the law, the social context of its existence may also be identified by the conditionality of the development of social relations by a valid 
and effective set of legal norms implemented in it. As a result, the society and the law are interrelated, which must be respected and taken into account in their close scrutiny.

A very daunting place in tax law and tax policy as such is tax evasion. This is a phenomenon in a society whose development is much faster than the legislation in this area. While the economy has been increasingly globalizing for several decades, which is very visible in areas like the digital market, tax systems are lagging far behind, and there exists a suitable hotbed for different taxpayers' practices whose aim and intent is to reduce their own tax burdens. Most of this is visible in indirect taxes, such as value added tax and excise duties, but the income tax is also a painful place in the legislative process. Not to mention that while indirect taxes have a kind of harmonization, even if we could argue about it, direct taxes are, contrary to that, in the direct competence of the Member States of the European Union.

All of the previous proposals for a harmonized corporate tax base have come under the resistance of some European Union Member States. It has to be said that part of EU officials continues to be endeavored to implement it. The European Commission was discussing a transparent and fair tax regime in the EU during this period. Thanks to the widespread revelations of scandalous ways of large corporations avoiding paying their taxes, this is an extremely interesting and up-to-date discussion. All the more so at a time when States are forced to cut back on the basic spending for which there is, reportedly, not enough money. The proposal to harmonize direct taxes has already been in the EU institutions for discussion for four years and has ended with failure. The proposal has come across some Member States' disapproval and has been hibernating since then. I think there is a similar fate today, but for the Commission, the common tax base is an integral part of the plans to combat illegal and unfair tax tactics. Agreements on the automatic exchange of information on bank account holders with countries such as Switzerland, Liechtenstein, Andorra or Monaco, or pressure on tax havens, should go hand in hand with mending the EU. Tax havens are heavily used for aggressive tax planning, as some banking institutions have pointed out (European Newspapers, 2015).

The activity has so far focused on punishing individual cases, which is, in fact, ineffective. The Commission will examine the special regimes and future tax agreements that companies have concluded with countries such as Ireland or Luxembourg. In many of them, there are record-high fines for breaches of competition rules threatening. However, a system solution is needed. The agreement on a common tax base is part of it. It will transparently determine what is taxable in the common European market and where exemptions are possible. It is to ensure that companies pay taxes in the country where they do their business. After all, they should compete with product innovation, not with the capabilities and tactics 
of tax advisors and legal services. However, any tax decision must be unanimously agreed by all of the EU Member States, and here the Commission will experience resistance. For the many EU Member States, this issue is taboo. The speech on "sovereignty in the tax area", however, is difficult to conceive in any other way but fogging and retention of the current state of affairs that suits the States. This is about specific economic interests. Inadequacies in the tax rules of Ireland, the welcoming approach of the Luxembourg authorities, the labyrinth of box office companies on the islands under the British crown rule, or the particularly advantageous taxation of intellectual property in the Netherlands certainly suit certain groups of particular interest. However, this cannot be considered a national interest and advocate in this way a dissenting opinion on an equitable tax regime in the EU.

Very interesting was also the debate in the European Parliament, where Members demand more equitable taxation. The EU Member States must be more open about their national tax decisions, as unfair tax competition distorts competition between businesses and can lead to a tax cut to a minimum. It is generally known that differences in national tax rules lead to fragmentation of the EU single market.

The European Commission has presented a package on fiscal transparency as part of its ambitious programme to combat tax evasion and harmful tax competition in the EU. A key element of this package of fiscal transparency measures is the introduction of an automatic exchange of information on binding tax opinions in the Member States. The objective of the tax transparency package is to ensure that the Member States receive information to protect their tax bases and effectively deal with companies that try to avoid paying a fair share of the tax. The central element of the transparency package presented by the Commission is a legislative proposal to improve Member States' cooperation on cross-border binding tax opinions, which should be the beginning of a new era of transparency. At present, the Member States are exchanging very little information on their binding tax opinions. The issue of a binding tax position as being relevant to another EU country is decided by the Member State. As a result, the Member States often do not know about cross-border binding tax opinions issued in other EU countries that may affect their own tax bases. Some companies abuse the lack of transparency in binding tax positions and artificially reduce their tax obligations. In order to remedy this situation, the Commission proposes to remove this space for free decision-making and interpretation. The Member States will automatically be required to exchange information on their binding tax position. National tax authorities will have to send a short report to all other Member States every three months on all the crossborder binding tax opinions they have issued. The Member States will then be able to ask for more detailed information on a specific tax position. By automatically exchanging the information on binding tax positions, the Member States will be 
able to detect and take appropriate action against certain unfair tax practices of companies. In addition, a sounder tax competition should be encouraged as it would be less likely that tax authorities would offer companies selective tax treatment when they can be controlled by partner tax authorities from other Member States.

In the field of tax transparency, there are increasingly frequent EU-level discussions on the assessment of new requirements for multinational companies. The Commission will examine whether new requirements for transparency, such as the disclosure of certain tax information by multinational companies, can be introduced for companies. The objectives, benefits, and risks of any such initiative need to be carefully considered. The Commission will, therefore, assess the impact of possible additional transparency requirements in order to make an informed decision.

One of the EU instruments is included in the Code of Conduct for business taxation. It should be a tool to ensure a fair tax competition for businesses. It sets out the criteria for determining whether or not the tax regime is harmful and requires the Member States to abolish any harmful tax measures that are contrary to the Code. The Member States regularly meet to assess compliance with the Code. In recent years, however, the effectiveness of the Code for the elimination of harmful tax regimes has fallen, as its criteria do not take into account more sophisticated systems to avoid tax evasion. The Commission, together with the Member States, will, therefore, revise both the Code of Conduct and the Code of Conduct Group mandate in order to make it more effective to ensure fair and transparent tax competition within the EU (European Newspaper, 2015).

The impact of the EU on tackling tax evasion cannot just remain on a declarative level. It will be necessary to monitor the adoption of all the measures that will help reduce tax evasion and detect tax evasion. The Commission and Eurostat, together with the Member States, are trying to find out how reliable estimates of tax evasion can be obtained. There is increasing evidence that tax evasion and tax avoidance are ubiquitous and cause significant revenue losses.

In general, tax evasion may be characterized as the result of the economic behavior of taxpayers, minimizing their tax burden to the State. In part of the textbooks, especially of economic focus, we find that the optimal environment for tax evasion is rather in a non-standard economy than in countries where the economic situation is standard. Especially in the transforming economies, the growth of illegal non-payment of taxes has also affected other factors. These factors may include the introduction of the VAT (Value Added Tax), which was something new to the transforming economies, but which is linked to demanding administrative requirements and processing itself (Červená, 2016). It also undoubtedly includes tax legislation, notably frequent changes in regulations, the introduction of many 
exceptions, but also lack of clarity and complexity of the legislation, lack of qualified staff ensuring tax accounting in accordance with tax rules and extensive customs shortcomings, as customs offices are also tax administrators (Strelcova, 2006: 97). It should be noted, however, that tax evasion and its exact definition are much more complicated than we often encounter. The European Commission, which recently launched a series of investigations into alleged tax agreements by which the Member States should favor large companies, also pays special attention to this issue. The EU Parliament has set up a special committee on tax decisions and tax measures.

What is the obvious difference between tax agreements, tax frauds, and tax evasion in a simplified form? For tax agreements (tax rulings), there is always one specific company or person. It could be said that this is a legal act that provides taxpayers with legal certainty and transparency. Tax fraud may be characterized as a deliberate circumvention of rules in order to avoid paying taxes. What, however, is very important from a legal point of view is that this should be the deliberate action, and proving this fact is very complex and often unachievable (Románová, 2017; Románová, 2015). In addition, there is one more term that is often used, namely tax optimization, which is legal, unlike tax fraud, but can legally be considered illegal, especially in those cases where a taxpayer abuses legal remedies to eliminate tax liability. Thus, if the tax is optimized, it means that the statutory options or gaps in the law are used.

Illegal tax avoidance and the level of circumventing taxation results in tax evasion that damages soundness of public finance. Tax evasion is a characteristic negative phenomenon of the present, just like the shadow economy. Illicit tax evasion is also done by manipulating the accounting data. The most important reasons for tax evasion can be the following: economic factors, legislative factors, socio-political factors, tax-technical factors, psychological factors, social and ethical factors (Slepecký, 2008).

\section{Conclusions}

The term of tax optimization is used more often than legal tax evasion, it is also more acceptable and does not give rise to suspicions of committing a crime in the public. Certainly, it is better to name things that most taxpayers would not want to implement, but they are often forced to do so, and adapt their activity primarily to their own benefit, even on the "edge of the law". Thus, if the tax is optimized, it means that the law is also used with its shortcomings or through "holes" in the law. From the very definition of tax optimization, we can characterize some of the principles that are used through this institute. These options include the use of a non- 
Tax Law and Its Impact on the State Budget

taxable minimum, non-taxable income, and various exemptions, which are defined in the laws, different options for applying costs, costs of different legal forms of doing business, different types of business contractual relationships - between the firms, as well as between companies and individuals.

The State has already implemented a series of measures that should partially reduce tax evasion, but it should be noted that as legislators are looking for ways to prevent tax evasion, taxpayers also use all available means to avoid paying the taxes or minimizing their amount. Mutual cooperation among the countries not only within the EU but globally, should help to improve the situation in tax collection in the future.

\section{References}

Babčák, V:: Slovenské daňové právo (Slovak tax Law), Bratislava: EPOS, 2012.

Beňová, E. et al.: Financie a mena (Finances and Currency), Bratislava: Iura Edition, 2005.

Boguszak, J. et al.: Teorie práva (Theory of Law), Praha: 2004.

Brôstl, A. et al.: Teória práva (Theory of Law), Košice: P.J. Šafárik University in Košice, 2004.

Červená, K.: Business Environment in the Slovak Republic after the Accession of the SR to EU Legal and Economic Aspects, Gospodarka i finanse w warunkach globalizacji (Economy and Finances in the Conditions of Globalisation), Toruń: Wyższa Szkoła Bankowa, 2008.

Červená, K. et al.: DPH - genéza a stav de lege lata na území Slovenska: podkapitola 1.1 (VAT - Development and Current State in the Area of Slovakia: subchapter 1.1), Daň z přidané hodnoty z perspektivy aktuálních legislativních změn (Value Added Tax in the Light of Current Legislative Changes), Olomouc: Iuridicum Olomoucense, 2016.

Harvánek, J. et al.: Teorie práva (Theory of Law), Plzeň: Aleš Čeňek, 2008.

Kubů, L. et al.: Teorie práva (Theory of Law), Praha: Linde, 2007.

Knapp, V.: Teorie práva (Theory of Law), Praha: C.H. Beck, 1995.

Medved', J. et al.: Verejné financie (Public Finance), Bratislava: Sprint, 2011.

Prusák, J.: Teória práva (Theory of Law), Bratislava: Komensky University, 1999.

Románová, A.: Boj proti obchádzaniu zákona pri priamych daniach v SR (Fight Against Circumvention of Law in Direct Taxation), Days of Law 2016, Brno: Masaryk University, 2017.

Románová, A.: The New Anti Abuse Rule in Slovak Tax Law: Strengtening of Legal Certainty? System of Financial law : System of Tax Law, Brno: Masaryk University, 2015. 
Románová, A. et al.: Assessment of the Impact of EU Law on National Procedural Tax Legislation, SGEM Conference on Political Sciences Law, Finance Economics \& Tourism, Sofia: Stef92 Technology, 2014.

Schulzová, A. et al.: Daňovníctvo: daňová teória a politika (Taxation: Tax Theory and Policy), Bratislava: Iura Edition, 2011.

Schultzová, A.: Daňovníctvo (Taxation), Bratislava: Iura Edition, 2007.

Sivák, R. et al.: Verejné financie (Public Finance), Bratislava: Iura Edition, 2007.

Slepecký, J. et al.: Ekonomické dôsledky katastrof (Economic Consequences of Disasters), Žilina: Edis, 2008.

Strelcova, S.: Konvergencia ekonomík Českej a Slovenskej republiky k EÚ (The Convergence of Czech and Slovak Economies to the EU), Krízový manažment (Crisis Management) no. 2 (2006).

Takto komisia bojuje proti vyhýbaniu sa daňovým povinnostiam právnických osôb (Thus the Commission Fights Against Tax Avoidance by Legal Entities), Európske noviny (European Newspapers), 2015. www.europskenoviny.sk.

Ulpianus, D I, I, I, 2.

Weinberger, O.: Inštitucionalizmus. Nová teória konania práva a demokrácie (Institutionalism. New Theory of Law and Democracy), Bratislava: Archa, 1995.

Weinberger, O.: Moral und Vernunft, Beiträge zur Ethik, Gerechtigkeitstheorie und Normenlogik (Morality and Reason, Contributions to Ethics, Justice Theory and Normative Logic), Vienna - Cologne - Weimar, 1992. 